\title{
A poesia palestina como resistência à barbárie
}

\author{
Luís Eustáquio Soares ${ }^{\mathrm{i}}$ \\ Fábio Henrique Araújo Santos ${ }^{\mathrm{ii}}$ \\ Marcos Rocha Matiasiii
}

\section{RESUMO}

Este estudo tem como objetivo analisar a questão do antissemitismo contra os árabes, a partir da análise de poemas (de diferentes poetas palestinos) presentes na antologia intitulada Poesia Palestina de Combate (1981), organizada por Abdellatif Laâbi. Para tanto, sem deixar de analisar as diferenças e semelhanças entre o antissemitismo judaico e árabe, partiremos de uma perspectiva teórica interdisciplinar, em interlocução com Edward Said, de A questão palestina (2012) e Orientalismo: o Oriente como invenção do Ocidente (1990); com o historiador britânico, Arnold Toynbee, de A história e a moral no Oriente Médio (1970); com o filósofo da história, Domenico Losurdo, de A linguagem do império: léxico da ideologia estadunidense (2010); com, finalmente, György Lukács, de Estetica: Cuestiones previas y de principio (1966) e Marx e Engels como historiadores de literatura (2016). Objetiva-se analisar os poemas dos seguintes poetas da citada antologia: "Cóleras e tristeza", "Canto para os homens (fragmento)", Crônicas da dor Palestina", de Mahmud Darwich; e "O enforcado", de Salim Jabran, escolhidos porque expressam com mais contundência a voz coletiva do povo palestino a partir de um esclarecimento lírico emancipador.

Palavras-chave: Antissemitismo; Orientalismo; Palestina.

\begin{abstract}
This text aims to analyze the issue of anti-Semitism against the Arabs, based on the analysis of poems (from different Palestinian poets) present in the anthology entitled Palestinian Combat Poetry (1981), organized by Abdellatif Laâbi. To do so, without failing to analyze the differences and similarities between Jewish and Arab anti-Semitism,

\footnotetext{
${ }^{\text {i }}$ Possui formação pós-doc em Letras e atualmente é professor associado IV de Teoria da Literatura e Literaturas de Língua Portuguesa na Universidade Federal do Espírito Santo (UFES) e pesquisador de produtividade de pesquisa do CNPq.

ORCID: https://orcid.org/0000-0002-1430-4705 | luiseustaquiosoares@gmail.com

ii Licenciado em Letras pela Universidade Federal de Minas Gerais (UFMG), mestre e doutorando em Letras pela Universidade Federal do Espírito Santo (UFES). É docente no Instituto Federal de Minas Gerais (IFMG), no campus de Ribeirão das Neves.

ORCID: https://orcid.org/0000-0002-8851-7674 | fabio.henrique@ifmg.edu.br

iii Graduado em Letras pela Universidade Federal de Minas Gerais (UFMG), mestre em Estudos Literários pelo Programa de Pós Graduação em Letras da Universidade Federal do Espírito Santo (UFES) e professor de Língua Portuguesa da Rede Estadual do Espírito Santo.

ORCID: https://orcid.org/0000-0003-3193-3869 | marcosrocha80@yahoo.com.br
} 
we will start from an interdisciplinary theoretical perspective, in dialogue with Edward Said, from The Palestinian Question (2012) and Orientalism: the East as an invention of the West (1990) ; with the British historian, Arnold Toynbee, from History and morals in the Middle East (1970); with the philosopher of history, Domenico Losurdo, from The language of the empire: lexicon of the American ideology (2010); with, finally, György Lukács, from Estetica: Cuestiones previas y de principio (1966) and Marx and Engels as historians of literature (2016). The objective is to analyze the poems of the following poets of the mentioned anthology: "Wrath and Sadness", "Song for Men (fragment)", Chronicles of Palestine Pain", by Mahmud Darwich; and "The Hanged Man" by Salim Jabran, chosen because they express more forcefully the collective voice of the Palestinian people from an emancipatory lyrical clarification.

Keywords: Anti-Semitism; orientalism; Palestine.

\section{INTRODUÇÃO}

O antissemitismo é prática de discriminação racial de longa história, geralmente associado à discriminação racista aos judeus, com longa tradição no Ocidente, sobretudo no contexto medieval e no período de emergência do imperialismo, no contexto europeu, nos finais do século XIX.

Partimos, neste artigo, da hipótese de que existam dois antissemitismos: um que ocorreu no interior da própria história do Ocidente, tendo como foco o povo judeu, então marcado pela condição aporética de ser ocidental e de não ser ocidental, em função da relação metafísica entre Ocidente e sua religião tornada oficial: o cristianismo.

O outro antissemitismo é propriamente colonial, tendo relação com o processo de expansão da Europa. É o antissemitismo contra os povos árabes, que também podem ser chamados de semitas, como semitas foram também os assírios, babilônios, arameus, cananeus, fenícios, se a referência a ser adotada for antiguidade.

O sistema colonial europeu, ao expandir-se, dilatou também o racismo, fomentando o antissemitismo árabe, especialmente após a Primeira Guerra Mundial, com a derrota do Império Otomano e a consequente partilha dos países do grande Oriente Médio entre as potências imperialistas vencedoras, especialmente Inglaterra e França.

Povos (com identidades étnicas, linguísticas, religiosas comuns) foram divididos com o objetivo explícito de dominá-los, submetê-los, ecoando, nesse processo, algumas 
centenas de anos de dominação do Ocidente, que teve início com a invasão e ocupação das Américas pelos espanhóis e portugueses e, ato contínuo, Inglaterra, Holanda e França, avançando com a marcha colonizadora ocidental, sobrepujando Portugal e Espanha por meio das Companhias das Índias Orientais, a britânica, fundada em 1600, a neerlandesa, em 1621; e a francesa, em 1664.

Mistos de empreendimentos estatais e privados, assumindo a forma destes últimos, as Companhias Marítimas Orientais atuavam simultaneamente em diversas regiões do planeta, sobretudo a inglesa, realizando guerras como, por exemplo, as duas Guerras do Ópio da Inglaterra contra a China, a primeira, de 1839 a 1841; e a segunda, de 1856 a 1860, já com a participação de um consórcio de países, incluindo EUA, com o objetivo de acumular forças para submeter o Império Celeste.

Passado o período propriamente colonial, com o advento do modo de produção capitalista, a expansão do capital, no primeiro momento inglês, não cessou de impor-se contra os povos, condenando-os ao setor primário-exportador da economia, ao mesmo tempo que ampliava os mercados por meio de relações capitalistas de produção que funcionavam e funcionam da seguinte maneira: capital industrial, com mais-valor relativo, para as Metrópoles ocidentais; primarização econômica, com mais-valor absoluto, para a periferia do sistema.

Em diálogo com Edward Said (1990, p. 13), orientalismo se constitui como “[...] o lugar especial ocupado pelo Oriente na experiência ocidental europeia". E que experiência é essa? É a que diz respeito ao violento processo de expansão do Ocidente; processo que engendrou campos discursivos e relações sociais de produção baseados na ideologia do colonialismo e, portanto, na justificativa simbólico-prática da superioridade étnica, cultural, tecnológica e religiosa das Metrópoles ocidentais em relação ao Oriente.

A história do sistema colonial europeu foi a referência por meio da qual a suposta inferioridade dos orientais, em relação aos ocidentais, foi, sem cessar, defendida, justificada, tendo em vista o que pode ser chamado de "ocidentalismo", razão pela qual, reduzida à sua simplicidade dicotômica (Ocidente versus Oriente), com Said:

$\mathrm{O}$ argumento, quando reduzido à sua forma mais simples, era claro, preciso, fácil de apreender. Há ocidentais e há orientais. Os primeiros dominam; os segundos devem ser dominados, o que costuma querer dizer que suas terras devem ser ocupadas, seus assuntos internos rigidamente controlados, seu sangue e seu tesouro postos à disposição de uma potência ocidental (SAID, 1990, p. 46). 
Esses campos discursivos e práticas coloniais, produzidos pelos países colonizadores, incorporam um traço ideológico a mais no final do século XIX, a saber: a categoria de raça, "cientificamente" desenvolvida na fase imperialista do capitalismo, com o objetivo de justificar a superioridade branca europeia em relação à inferioridade étnica dos outros povos.

Considerando que tanto os árabes quanto os judeus são povos semitas, o antissemitismo pode ser interpretado como o efeito trágico do orientalismo, embora com uma diferença importante: o antissemitismo judaico é anterior ao período de expansão colonial e capitalista do Ocidente, tendo relação com a escravidão dos judeus pelo império romano e com o conturbado processo de constituição metafísica do Ocidente, indissociável da captura do cristianismo pelo impérios europeus em formação e pela segregação do judaísmo.

No interior da própria história de constituição mitológica do Ocidente, como unidade discursiva própria, os judeus se tornaram, talvez, a primeira alteridade (o outro em relação ao mesmo) ocidental; uma alteridade aporética, como dissemos, porque ao mesmo tempo europeia e não europeia.

A solução final para os judeus, imposta por Hitler, com o Holocausto, na primeira metade do século XX, assim interpretamos, tem relação direta com a fase imperialista do orientalismo, sobretudo considerando a questão da superioridade racial. Nesse contexto, já não havia espaço para aporias: os judeus, esses europeus sem ser, eram inferiores etnicamente.

A aporia europeu não europeu nunca esteve presente na relação europeu e árabes, de modo que estes últimos se tornaram, no processo, alteridades absolutas, razão pela qual o orientalismo, nos termos de Said, pode ser analisado como a ideologia do antissemitismo árabe, ainda que esta última tenha sido acionada, no âmbito do nazismo, para romper com aporia semítico-judaica, ocidental versus não ocidental, condenando os hebreus à condição de alteridade absoluta e, portanto, de vidas nuas e, assim, matáveis.

\section{A DIALÉTICA DO ESCLARECIMENTO REGRESSIVA E O REALISMO ESTÉTICO PALESTINO}


Os filósofos alemães Theodor W. Adorno e Max Horkheimer publicaram, em 1947, a obra Dialética do esclarecimento (1985). No momento pós-guerra, logo no prefácio, os autores trazem à tona a reflexão sobre a ambiguidade do esclarecimento:

\begin{abstract}
A aporia com que defrontamos em nosso trabalho revela-se assim como o primeiro objeto a investigar: a autodestruição do esclarecimento. Não alimentamos dúvida nenhuma - e nisso reside nossa petitio principii - e que a liberdade na sociedade é inseparável do pensamento esclarecedor. Contudo, acreditamos ter reconhecido com a mesma clareza que o próprio conceito desse pensamento, tanto quanto as formas históricas concretas, as instituições com as quais está entrelaçado, contém o germe para a regressão que hoje tem lugar por toda a parte. Se o esclarecimento não acolhe dentro de si a reflexão sobre esse elemento regressivo, ele está selando o seu próprio destino. Abandonando a seus inimigos a reflexão sobre o elemento destrutivo do progresso, o pensamento cegamente pragmatizado perde seu caráter superador e, por isso, também sua relação com a verdade. A disposição enigmática das massas educadas tecnologicamente a deixar dominar-se pelo fascínio de um despotismo qualquer, sua afinidade autodestrutiva com a paranoia racista, todo esse absurdo incompreendido manifesta a fraqueza do poder de compreensão do pensamento teórico atual (ADORNO; HORKHEIMER, 1985, p. 13).
\end{abstract}

O esclarecimento, para Adorno e Horkheimer (1985), tem, em diálogo com o trecho citado, duas dimensões, uma progressiva e outra regressiva. A primeira tem relação com a perspectiva de Immanuel Kant, por exemplo, tendo em vista o ensaio de 1783, “Resposta à pergunta: o que é o esclarecimento?” (Aufklärung), texto em que o filósofo alemão defendeu o esclarecimento que emancipa, a partir do conhecimento objetivo da realidade e da história.

A segunda, por sua vez, com Adorno e Horkheimer, diz respeito ao esclarecimento regressivo e faz-se de maneira indiscernível à relação saber/poder/dominação sobre o trabalho e sobre a natureza, levando ao desencantamento do mundo na medida em que avança a razão instrumental, que é a que separa sujeito do saber do objetivo do saber, como é possível visualizar no seguinte trecho do livro em tela:

O programa do esclarecimento era o desencantamento do mundo. Sua meta era dissolver os mitos e substituir a imaginação pelo saber. (...), portanto, a superioridade do homem está no saber, disso não há dúvida. (...) O casamento feliz entre o entendimento humano e a natureza das coisas que ele tem em mente é patriarcal: o entendimento que vence a superstição deve imperar sobre a natureza desencantada. O saber que é poder não conhece barreira alguma, nem na escravização da criatura, nem na complacência em face os senhores do mundo. Do mesmo modo que está a serviço de todos os fins da economia burguesa na fábrica e no campo de batalha, assim também está à disposição dos empresários, não importa sua origem. Os reis não controlam a técnica mais diretamente do que os comerciantes: ela é tão democrática quanto o sistema 
econômico com o qual se desenvolve. A técnica é a essência desse saber, que não visa conceitos e imagens, nem o prazer do discernimento, mas o método, a utilização do trabalho de outros [...] (ADORNO; HORKHEIMER, 1985, p. 17-18).

Na pré-história e na Idade Média, os fenômenos da natureza eram explicados a partir dos mitos. Havia uma relação de integração entre o sujeito (homem) e o objeto (natureza). No momento em que o homem passou a dominar a natureza por meio do conhecimento técnico-científico, os fenômenos naturais deixaram de ser explicados pelos mitos em detrimento da razão. Nesse momento, houve uma cisão entre o sujeito e objeto, na medida em que o homem passou a subjugar a natureza e o próprio homem com fins lucrativos, dentro dos moldes capitalistas.

Dessa forma então, segundo Adorno, percebemos que, no interior do próprio esclarecimento, há um resquício de crueldade, pois o homem, utilizando o conhecimento técnico-científico, é capaz de agredir a natureza e explorar o próprio homem, para obtenção de poder e riqueza.

Tomemos como exemplo dessa ambiguidade em torno do esclarecimento, evidenciada no penúltimo capítulo da obra em tela, "Elementos do Antissemitismo: Limites do esclarecimento", o seguinte trecho: "Para os fascistas, os judeus não são uma minoria, mas a antirraça, o princípio negativo enquanto tal; de sua exterminação dependeria a felicidade do mundo" (ADORNO; HORKHEIMER, 1985, p. 139).

Como ficou assinalado na introdução deste artigo, se o judeu, no interior da história metafísica da Europa, sobretudo em sua fase imperialista, incorpora a condição aporética de ser e não ser europeu, com o nazismo, a aporia foi definitivamente rompida com a proposição de uma solução final, com o extermínio de todo um povo.

Como não europeu e sobretudo como não alemão e assim não ariano, caberia ao sistema integral de propaganda nazista convencer ao povo alemão de que os judeus deveriam ser exterminados. Evidencia-se, desse modo, a radicalização sem precedentes do esclarecimento regressivo, como assinalaram Adorno e Horkheimer no fragmento abaixo:

Se o esclarecimento não acolhe dentro de si a reflexão sobre esse elemento regressivo, ele está selando o seu próprio destino. Abandonando a seus inimigos a reflexão sobre o elemento destrutivo do progresso, o pensamento cegamente pragmatizado perde seu caráter superador e, por isso, também sua relação com a verdade. A disposição enigmática das massas educadas 
tecnologicamente a deixar dominar-se pelo fascínio de um despotismo qualquer, sua afinidade autodestrutiva com a paranoia racista, todo esse absurdo incompreendido manifesta a fraqueza do poder de compreensão do pensamento teórico atual (ADORNO; HORKHEIMER,1985, p. 13).

Goebbels, ministro da propaganda do partido nazista, utilizava os avanços tecnológicos alcançados pela humanidade no setor de comunicação de massa, como rádio e o cinema, com o objetivo de convencer a população alemã de que o povo judeu era um inimigo a ser eliminado, assim, justificando o massacre do Holocausto.

Goebbels valeu-se, portanto, da razão instrumental, no limite do esclarecimento regressivo, usando os últimos avanços tecnológicos, para, também, levar ao extremo o racismo de Estado. Utilizou-se dos meios de comunicação não apenas para sedimentar ódio antissemita à população alemã, mas também para implementar mecanismos sofisticados de assassinato coletivo, promovendo um verdadeiro genocídio ao povo judeu.

\section{A POLÍTICA SIONISTA: A REPRODUÇÃO DO AUTORITARISMO NA PALESTINA}

Reproduzindo a política racista e autoritária do Estado alemão, o Estado sionista judeu ocupa agora não mais o papel de oprimido, mas de opressor. Neste artigo, a propósito, assumimos a hipótese de que o sionismo, como ideologia e, portanto, como falsa consciência, incorporou os preconceitos do orientalismo, assumindo integralmente o lado de cá da aporia europeu não europeu, na pressuposição de que os judeus sejam uma espécie esdrúxula de Antigo Testamento do processo de constituição metafísica da Europa; o patriarca do Ocidente.

Um dos ideólogos dessa metamorfose, na fase imperialista da ideologia do colonialismo, foi Theodor Herzl. O fundador do moderno Sionismo político foi também o propugnador da criação de um Estado próprio para os judeus, evidentemente fora da Europa. Gradativamente, iniciou-se um processo intenso de migração judaica para a Palestina.

A propósito, já no século XX, em novembro de 1917, por meio da Declaração de Balfour, o imperialismo britânico, do qual Herzl foi um "servidor", institucionalizou a migração que já ocorria, ao definir sem meias palavras a região da Palestina como o sítio histórico-geográfico da pátria dos judeus. 
O efeito trágico dessa decisão foi a gradativa dissolução do Estado árabe da Palestina e o deslocamento do esclarecimento regressivo para os árabes, configurando, desse modo, um novo estágio do orientalismo. Edward Said, em sua obra A questão da Palestina (2012) fez uma reflexão importante a propósito:

\begin{abstract}
A favor dos sionistas, lorde Rotschild se correspondeu com o governo britânico na fase preparatória do anúncio da declaração de Balfour. O memorando, datado de 18 de julho de 1917, trata do princípio de que a Palestina deve ser reconstituída como a pátria do povo judeu (...). No entanto, a 'reconstituição' ou 'reconstrução' implica inequivocamente que a configuração da Palestina que incluía centenas de milhares de árabes - deveria ser dissolvida (como ou onde isso deveria ocorrer não está muito claro), para que em seu lugar surgisse um novo Estado judeu. O tom dessas declarações deixa de fora qualquer referência explícita ao fato, sem dúvida, nenhum inconveniente, de que o país já estava constituído (ainda que como colônia) e era bastante improvável que seus habitantes ficassem satisfeitos que ele fosse 'reconstituído' por uma nova força colonial. Mas as declarações em si são corretas: a Palestina foi reconstruída, restabelecida. (SAID, 2012, p. 16).
\end{abstract}

No trecho acima, Said questionou sobre o modo como centenas de milhares de árabes foram desapropriados de suas terras a fim de atender aos objetivos sionistas. Essa política mudou o destino de pelo menos 700 mil árabes e seus descendentes, como destacou o autor de Cultura e imperialismo (1993) no seguinte fragmento de A questão palestina: "Essa não é a mera expressão de uma opinião: foi a declaração de uma política que mudou radicalmente o curso da história, se não de todo o mundo, certamente dos 700 mil árabes e seus descendentes cujas terras estavam sendo condenadas" (SAID, 2012, p. 19-20). Para se ter uma ideia da quantidade de árabes que ocupava a Palestina nesse período, Said nos forneceu dados do censo da época:

\footnotetext{
O censo, que é a única fonte confiável de que dispomos sobre a realidade demográfica daquela época (apesar de seus números consideravelmente subestimados, ele tem sido usado com frequência pelos historiadores israelenses), apresenta em 1914, uma população de "689.272 pessoas, das quais não mais (e talvez menos) de 60 mil judeus". O censo mostra ainda que, em 1922, cerca de 590.890 (78\%) eram mulçumanos; 73.024 (9,6\%), majoritariamente árabes, embora incluíssem alguns britânicos e outros europeus; menos de 10 mil (1\%) consistiam em outros; e 83.794 (11\%) eram judeus (SAID, 2012, p. 20).
}

O projeto sionista e imperialista dos países europeus com práticas colonialistas e racistas foi instituído nesse período na Palestina de forma perversa e desumana, ignorando 
os direitos e os interesses da população árabe que ocupava, majoritariamente, a região há séculos, como é possível ler no seguinte trecho do livro de Said em tela:

\begin{abstract}
Apesar de todas as diferenças (e elas eram inúmeras), tanto o imperialismo britânico quanto a visão sionista se unem no esforço de minimizar e até excluir os árabes da Palestina como algo de certo modo secundário e insignificante. Ambos elevam a importância moral de suas visões muito acima da mera presença de nativos num pedaço de território imensamente significativo. E ambas as visões fazem parte do ethos de uma mission civilisatrice europeia do século XIX, colonialista, racista - baseada em noções de desigualdade entre homens, raças e civilizações, uma desigualdade que permite as formas mais extremas de projeção de grandeza e de disciplina punitiva contra os desafortunados nativos, cuja existência, paradoxalmente, era negada (SAID, 2012, p. 22).
\end{abstract}

Segundo Said, em 1948, com a criação do estado de Israel pela ONU, cerca de 780 mil árabe-palestinos foram expropriados e desalojados de suas casas para facilitar a política de reconstituição e reconstrução da Palestina. E, após a ocupação israelense da Cisjordânia e de Gaza em 1967, foi implantada uma política de destruição nessas áreas. No fim de 1969, 7554 residências árabes foram arrasadas e, em 1971, 212 casas foram demolidas (SAID, 2012, p. 17).

Não há dúvidas, ponderamos, que a desumanização do palestino seja o efeito concreto e trágico da invenção do Oriente pelo Ocidente, considerando as coordenadas históricas da ideologia do colonialismo, tal como a definiu o historiador carioca Nelson Werneck Sodré no seguinte trecho do livro A ideologia do colonialismo de 1961:

\begin{abstract}
A ideologia do colonialismo começa a aparecer quando a expansão europeia se define nas descobertas ultramarinas. Adquire suas dimensões mais amplas, entretanto, quando, com a Revolução Industrial, determinadas áreas do mundo, a americana principalmente, emancipam-se de suas metrópoles, constituindose novos países. Mantida a estrutura colonial de produção, tais países deixam de gravitar em torno de suas metrópoles antigas, para gravitar em torno de outras, não tituladas assim, que regula, o seu desenvolvimento econômico. Através da ideologia do colonialismo, a camada dos povos oriundos da fase colonial estrita, é ganha - preparada que está pela sua condição de classe, - para aceitar a subordinação econômica, atribuindo-a a fatores não materiais: superioridade de raça, superioridade de clima, superioridade de situação geográfica, que predestinam as novas metrópoles. É em suma, a preparação ao imperialismo, a cuja agonia estamos assistindo, nesta fase de decomposição das áreas coloniais, sob novas condições (SODRÉ, 1961, p. 8).
\end{abstract}

Com suas diferenças, a ideologia do colonialismo é um efeito trágico de uma estrutura colonial de produção, servindo para justificá-la. As sucessivas invasões, ocupações, guerras e golpes do Ocidente em todo o mundo, e também no Oriente Médio, 
tem um único objetivo, a saber: impor uma estrutura colonial de produção, a partir, por exemplo, da tentativa de condenar a economia dos povos colonizados em agrárioexportadora, sem desenvolvimento da indústria, sem autonomia tecnológica. Diante desse contexto, restaria ao povo palestino reagir de diversas formas contra a opressão judaica. Do ponto de vista cultural, temos no interior do mundo árabe, o surgimento de produções poéticas de denúncia e combate a essa política imperialista e sionista, a partir de 1960.

\section{O APARECIMENTO DA POESIA PALESTINA DE COMBATE}

No decorrer da década de 60 do passado século, intensificando-se, após a Guerra dos Seis Dias de 1967, conflito que envolveu Israel e países árabes como Síria, Jordânia, Egito, culminando com a invasão da Faixa de Gaza, uma geração de poetas palestinos emergiu, abandonando a tradição formalista anterior, para afirmar uma dicção poética comprometida, nacionalista, indissociável da luta pela dignidade do povo palestino, de seu direito inalienável à vida, indiscernível do direito ao chão, à pátria, soberanamente.

Abdellatif Laâabi é um poeta marroquino, conhecido sobretudo por ter sido o fundador da censurada revista Souffle, epicentro de um significativo encontro não apenas de poetas e de escritores críticos, em relação à recorrente opressão ocidental, mas também de pintores, cineastas, intelectuais e pesquisadores não menos antenados com os grandes desafios das lutas pela emancipação dos povos do chamado terceiro mundo. Sensível à causa palestina, Laâbi organizou o livro A Poesia Palestina de Combate (1981) com o objetivo de divulgar as principais vozes poéticas que surgiram da resistência às sucessivas agressões israelenses. Essa obra é constituída de oitenta poemas, de vinte e quatro poetas palestinos. A maioria desses autores, refugiados de sua terra natal em virtude de perseguições políticas operadas pelo Estado de Israel, fez da poesia um instrumento de luta, sobrevivência e resistência à destruição sistemática do povo palestino. Os poemas, compostos em sua maioria de forma livre, resgatam, predominantemente, o clamor dos palestinos pelo direito à sua terra, à preservação de sua memória e à dignidade do seu povo. Antes dessa antologia, os primeiros textos foram produzidos de maneira semiclandestina, como assinala Laâbi no prefácio:

Os primeiros textos dos poetas aqui traduzidos apareceram, primeiro, numa publicação semiclandestina, a do grupo nacionalista Al-Ald (Terra), nos 
primeiros anos da década de 60. Até que, em 1964, o grupo foi dissolvido" (LAÂBI, 1981, p. 30).

Apesar da dissolução desse grupo, muitos poemas circularam de modo clandestino, dentro e fora de Israel: "nada pôde impedir que suas obras circulassem e saíssem clandestinamente de Israel para aparecerem nos países árabes (...), publicados sob a rubrica de poemas fugidos" (LAÂBI, 1981, p. 31). Posteriormente, depois da guerra de junho de 1967, algumas editoras árabes começaram a publicar os folhetos, divulgando assim, a poesia de combate no mundo árabe. Logo no prefácio dessa obra, observamos a relação entre poesia de combate e a Guerra dos Seis Dias no seguinte fragmento:

Foi essencialmente depois da guerra em junho de 1967 que se começou a conhecer no mundo árabe a produção dos poetas palestinos que viviam em Israel. Efetivamente, a partir desse ano, as editoras árabes - principalmente libanesas reeditaram os folhetos dos principais representantes dessa poesia, especialmente Samih Al Qassim, Mahmud Darwich e Tawfik Az-Zayad. No entanto, foi um intelectual palestino, Yusuf Al Khatib, autor de Poesias da Pátria Ocupada, emigrado para a Síria, quem tomou a iniciativa, uma vez fundada a Rádio Palestina em Damas, em 1964, de difundir os textos poéticos palestinos (LAÂBI, 1981, p. 13).

A “Guerra dos Seis Dias” foi uma grande derrota infringida por Israel aos povos árabes. Sua repercussão, por isso mesmo, foi e é imensa. Esse contexto motivou a projeção dos combativos poetas palestinos, que se tornaram conhecidos, principalmente no Oriente Médio, por terem conseguido transformar o poema em arma de conscientização do povo palestino, em resistência, ao imperialismo israelense. Portanto, a partir dessa guerra, a poesia palestina passou a ser efetivamente reconhecida no mundo árabe. Ela passou a ser porta-voz dos palestinos para o mundo, denunciando a ideologia sionista dos ocupantes nessa região, como se confirma no trecho abaixo, também retirado do prefácio escrito por Laâbi:

\footnotetext{
A poesia palestina converteu-se atualmente numa espécie de biblioteca sonora e ambulante do povo palestino. Superando seu papel de apelo ou de reivindicação, tentou reconstituir e tornar a situar na história, memória coletiva do povo. Por isso, quer ser uma resposta agressiva às mentiras do ocupante, à sua empresa de desumanização e sabotagem histórica. E, mais do que uma resposta, rapto, testemunho de presença e permanência, anúncio e preparação da queda do império bárbaro (LAÂBI, 1981, p. 33).
} 
Quando o verbo, sob o signo da poiesis, isto é, do poema que se faz na luta contra os opressores, encarna-se na consciência comum, no povo, adquire uma dimensão nova, coletiva, capaz de desmascarar as mentiras, as chantagens e a hipocrisia dos ocupantes, a serviço da supremacia ocidental. Nesse sentido, o papel da poesia palestina, além de denunciar as torturas, mortes e massacres contra o povo palestino, tem o objetivo de lutar contra o etnocídio também cometido por seus algozes, como destacado no fragmento abaixo:

Por toda parte a supremacia racial, religiosa e cultural judia, assim como a superioridade técnica, econômica e social israelense, são colocados em primeiro plano. O ensino que os árabes palestinos que vivem em Israel recebem é, pois, um ensino tipicamente colonial, como aquele do qual os povos antigamente colonizados e explorados guardaram triste lembrança (LAÂBI, 1981, p. 25).

Evidenciam-se, desse modo, as práticas racistas e etnocêntricas cometidas pelos judeus aos palestinos. $\mathrm{O}$ povo judeu, outrora oprimido e subjugado pelo antissemitismo alemão, exerce, nesta ocasião, a opressão, em seus vários aspectos, ao povo palestino. Dentro das escolas de Israel, os palestinos são alijados de um ensino que prestigie sua cultura, religião e etnia em detrimento da imposição ideológica judaica, como assinalou Laâbi no seguinte trecho da coletânea em tela:

\footnotetext{
Por fim, lembremos o estado de sítio cultural a que estão submetidos os árabes palestinos, separados de sua cultura histórica assim como da produção cultural dos outros países árabes. Pode-se dizer, sem medo de exagerar, que nesse plano a poesia palestina de combate é a única contraposição que podem opor aos desígnios sionistas, que é a única manifestação cultural em que esse povo 'refugiado em sua pátria' pode reencontrar-se e encontrar os elementos verídicos de sua história e de sua cultura (LAÂBI,1981, p. 26).
}

Diante "dos mecanismos da ideologia sionista que tendem a separar o povo árabe de suas raízes culturais e históricas" (LAÂBI, 1981, p. 27), a poesia palestina ressurge como instrumento de luta a fim de desmantelar os objetivos da ideologia do opressor e, ao mesmo tempo, reconstruir a memória coletiva do povo palestino, utilizando para isso a potência inerente a essa arte:

Fazendo uso das formas de expressão, das maneiras de contar e dos ritmos populares, os poetas palestinos não só conseguiram reabilitar aos olhos do povo, sua cultura depreciada pelo colonizador, como também recriar uma 
verdadeira cultura popular, esteticamente nova, capaz de transformar-se num vigoroso instrumento de luta. (LAÂBI, 1981, p. 27).

Dessa forma, pela combatividade indissociável da objetivação da realidade histórica, acreditamos que os poemas dos quais elegemos para este estudo: "Cóleras e tristeza"; "Canto para os homens (fragmentos)" e "Crônicas da dor Palestina", do poeta Mahmud Darwich e, também, "O enforcado", do poeta Salim Jabran, podem ser analisados como realistas, em temos da tradição marxista e especialmente em interlocução com o teórico húngaro György Lukács, por exemplo de Estética I: a peculiaridade do Estético (1966), livro no qual o realismo estético é assim definido: 1) a particularidade antropomórfica constitui a expressão de sua autonomia, como arte; 2) o particular é aquilo que constitui o humano no homem, em sua existência única; 3) a particularidade jamais pode ser representada por ela mesma, de modo reificado, porque, nesse caso, assumirá uma configuração antirrealista ou pseudorrealista; 4) a particularidade deve expressar-se a partir de uma opção ética irrecusável, sendo, assim, a particularidade do oprimido lutando contra as formas de alienação de sua época e, portanto, contra a sua própria desumanização; 5) a autonomia da arte, como expressão do particular antropomórfico, não abole a realidade histórico-social objetiva, partindo desta para expressar a dimensão antropomórfica do oprimido lutando contra a opressão que o desumaniza; 6) a particularidade que se humaniza, sendo a do oprimido, pela luta de classes, deixa de ser a particularidade pela particularidade da estética antirrealista e pseudorrealista para se tornar uma particularidade universal, pois a expressão particular de sua humanidade é também a da humanidade do humano no humano; de quaisquer.

Em Marx e o problema da decadência ideológica, publicado primeiramente em revista, em 1938 e, mais tarde, em 1952, na obra Marx e Engels como historiadores da Literatura, o teórico húngaro antecipava as categorias da estética realista. O seguinte trecho, por exemplo, é bastante ilustrativo:

\footnotetext{
O imenso poder social da literatura consiste exatamente e que nela o homem aparece de modo imediato, com toda a riqueza de sua vida interior e exterior, de uma maneira tão concreta como em nenhum outro âmbito do reflexo da realidade objetiva. A literatura é capaz de conferir às contradições, às lutas e aos conflitos da vida social da mesma forma que eles assumem na alma, na vida do homem; é capaz de mostrar as conexões desses conflitos do modo como eles se concentram no homem real. Esse é um espaço vasto e significativo de descoberta e investigação da realidade. Nesse nível, a literatura - realmente intensa e realista - consegue fornecer vivências e conhecimentos
} 
bastante novos, inesperados e essenciais até para o mais profundo conhecedor dos nexos sociais. (...) O avanço decisivo na direção de tal conhecimento, de tal vivencia literária do homem, consiste na vitória do realismo na literatura. (LUKÁCS, 2016, p. 131).

Portanto, para Lukács, o reflexo da realidade objetiva consiste numa análise dialética entre a representação das contradições da vida social e os conflitos internos das personagens. Quanto mais a literatura se aprofunda na interioridade das personagens como reflexos objetivos internos da realidade exterior; quanto mais há uma conexão entre a singularidade da personagem e a universalidade do ser social, historicamente constituído, mais a literatura alcança, de forma bem-sucedida, o triunfo do realismo autêntico. Para prosseguirmos, tomemos como exemplo, um trecho do poema "Cóleras e tristeza”, de Mahmud Darwich:

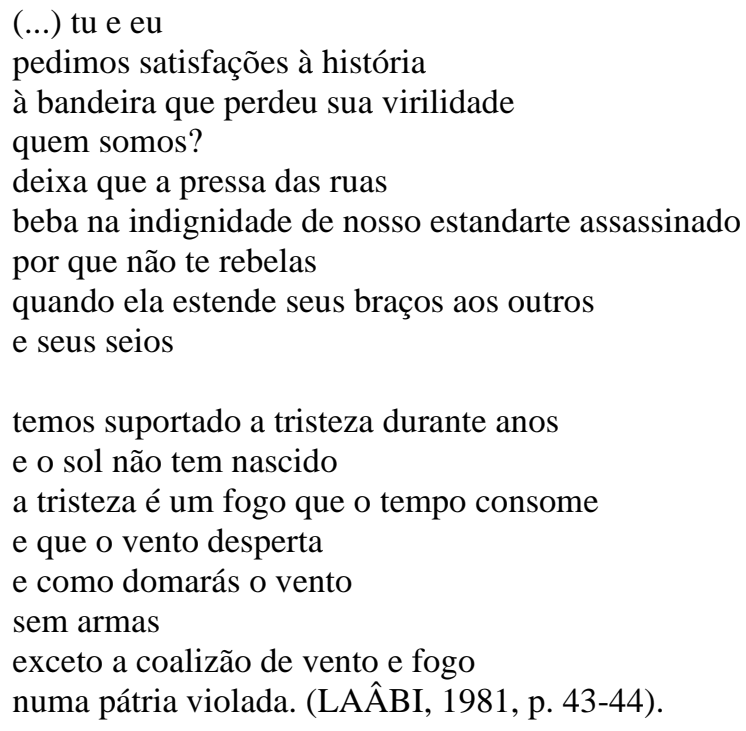

No fragmento desse poema, como o título indica, percebe-se a presença de um eu- lírico (essa particularidade antropomórfica do poema) encolerizado e entristecido. Na primeira estrofe, o sujeito poético reivindica à história, protestando contra a perda da soberania do seu próprio país, simbolizado pelo estandarte: "pedimos satisfação à história/ à bandeira que perdeu sua virilidade”. Em seguida, pergunta-se: “quem somos?”, questionamento que denuncia a destituição da identidade, destacando, assim, a desumanização fundamental, a saber: a destituição da identidade popular, nacional.

Ora, se a particularidade resiste à sua própria desumanização, lutando contra a opressão, ao se expressar na primeira pessoa do plural, mais que um retórico plural 
majestático, o eu-lírico assume-se como uma particularidade coletiva, universalizando-se e humanizando-se ao recusar igualmente o particular pelo particular, senha para a divisão e para a fatal derrota do oprimido.

Na segunda estrofe, o sujeito lírico, entristecido com a realidade do povo palestino diante de sua pátria violada, explora os elementos externos: o sol, o vento, o fogo, as armas, a partir de figuras de linguagem, como metáforas: "a tristeza é um tempo que o fogo consome", exprimindo, assim, a sua particularidade no plano singular-subjetivo.

Trata-se, pois, do "triunfo do realismo estético", ao conectar o singular, a interioridade, como dimensão subjetiva concreta do eu-lírico ao particular, a condição de palestino, sem deixar de pressupor a identidade coletiva: “quem somos?”.

Não obstante a tristeza sofrida pela difícil condição do palestino em Jerusalém, ainda há esperança e resistência, como é possível evidenciar no poema "Canto para os homens (fragmentos)" do mesmo poeta, Mahmud Darwich:

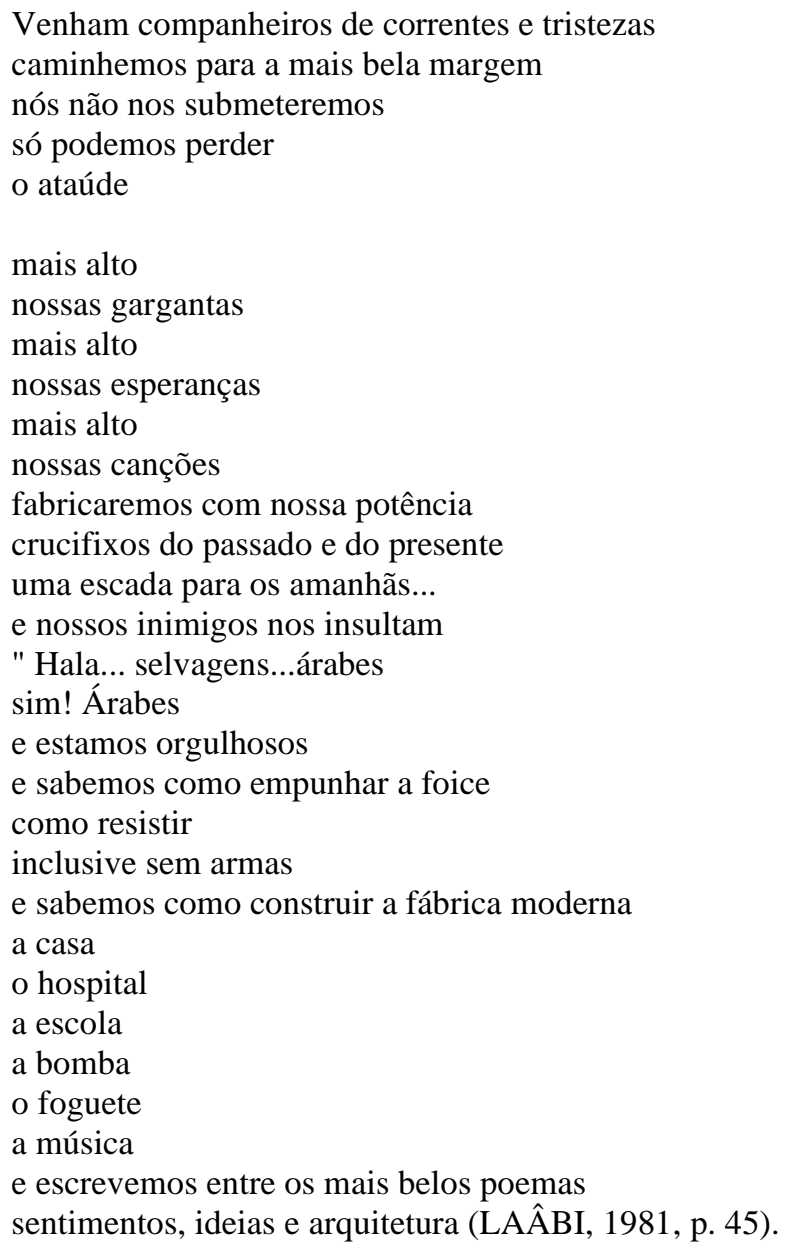


Seja por meio do uso do verbo "vir" na terceira pessoa do plural do modo imperativo, "venham companheiros de correntes e tristezas"; seja pelo verso escrito na primeira pessoa do plural, "nós não nos submeteremos", a primeira estrofe do poema em tela suplementa o poema anterior ao expressar a singularidade subjetiva, assim como a particularidade popular-nacional, em dimensão coletiva, conclamando a luta: "venham".

Como fica exposto no poema acima, a ocupação israelense no solo palestino não foi feita de forma harmônica e pacífica ao longo do século XX. O povo palestino defendeu seus direitos, lutando contra a desumanização colonial, consciente de que, em diálogo com os dois últimos versos da primeira estrofe, plasma-se o plano singular-subjetivo no particular-popular, sem deixar de afirmar o universal humano, ao salientar-se: "só podemos perder/ o ataúde".

O destaque do substantivo "ataúde", separado em um verso próprio, evidencia que a condição de mortal é a regra humana e, nesse sentido, é a vida que deve ser afirmada, coletivamente. A estrofe seguinte, ao dizer "mais alto/ nossas gargantas/mais alto/ nossas esperanças/ mais alto/ nossas canções", ratifica a luta comum tendo em vista não a aceitação da submissão, mas a dignidade altiva da luta, a única que humaniza o oprimido: "mais alto".

A voz lírica se expressa pela particularidade do oprimido, lutando contra a desumanização colonial, como é o caso do poema, sabe que a resistência não pode ser apenas retórica, razão pela qual pleiteia a dignidade como uma arma própria, em tempos de paz, bem entendido: "Inclusive sem armas/ e sabemos construir a fábrica moderna, / a casa/ o hospital, / a escola, / a bomba, / o foguete/ a música/ e escrevemos entre os mais belos poemas/ sentimentos, ideias e arquitetura".

No poema "Crônicas da dor Palestina", também do mesmo autor, Mahmud Darwich, o eu-lírico prossegue em sua altivez singular/particular/universal da seguinte maneira:

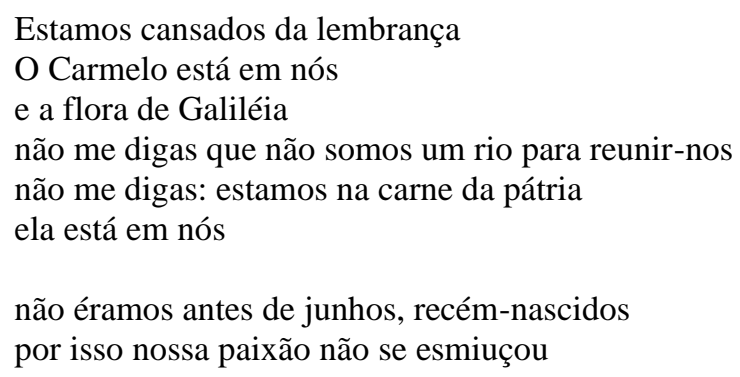




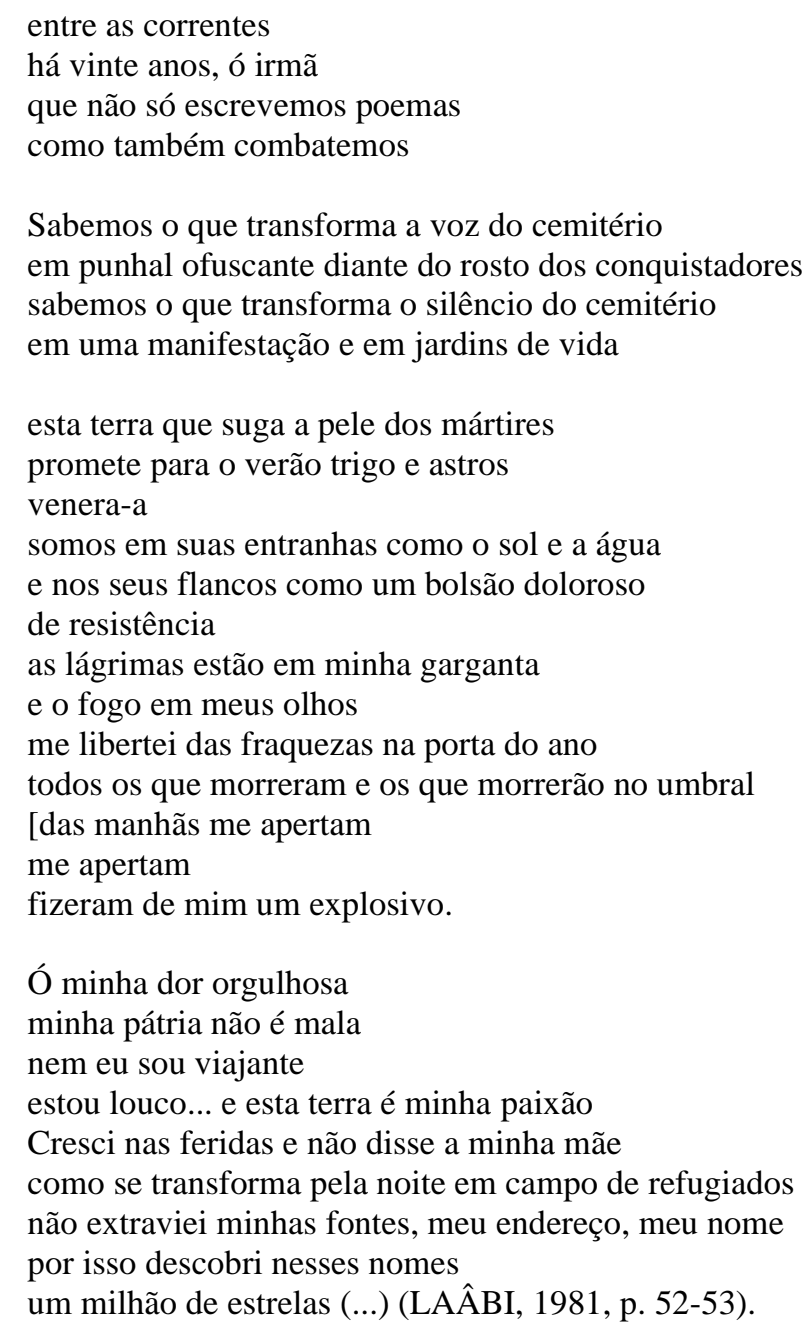

Nesse trecho do poema "Crônicas da dor Palestina", observamos uma declaração de paixão e apego do sujeito poético em relação à sagrada terra palestina: "estamos na carne da pátria/ ela está em nós/ não éramos antes de junhos, recém-nascidos/ por isso nossa paixão não se esmiuçou". Ao mesmo tempo, o eu-lírico transforma o apego a essa terra como um motivo para a resistência: "esta terra que suga a pele dos mártires/ promete para o verão trigo e astros/ venera-a/ somos em suas entranhas como o sol e a água/e nos seus flancos como um bolsão doloroso/ de resistência".

O sujeito poético, no poema em tela, expressa a sua dor, ao lamentar pela perda dos seus mártires, além disso, reforça o apego do palestino à sua terra, metaforizada pela imagem amalgamada entre os raios solares e água, ligados à terra. Por fim, o eu-lírico conclama o seu povo a resistir, por meio de uma constante e permanente relação dialética, formada pelas palavras perda, dor e resistência, em que o vocábulo "perda" pode ser interpretado como a regra, logo a tese; a dor, a antítese; e a resistência, por sua vez, o 
salto ontológico fundamental e universal da síntese aberta e antropomórfica da dialética do oprimido: a luta de classes. E, para finalizar, analisemos este poema, "O enforcado", agora do poeta Salim Jabran:

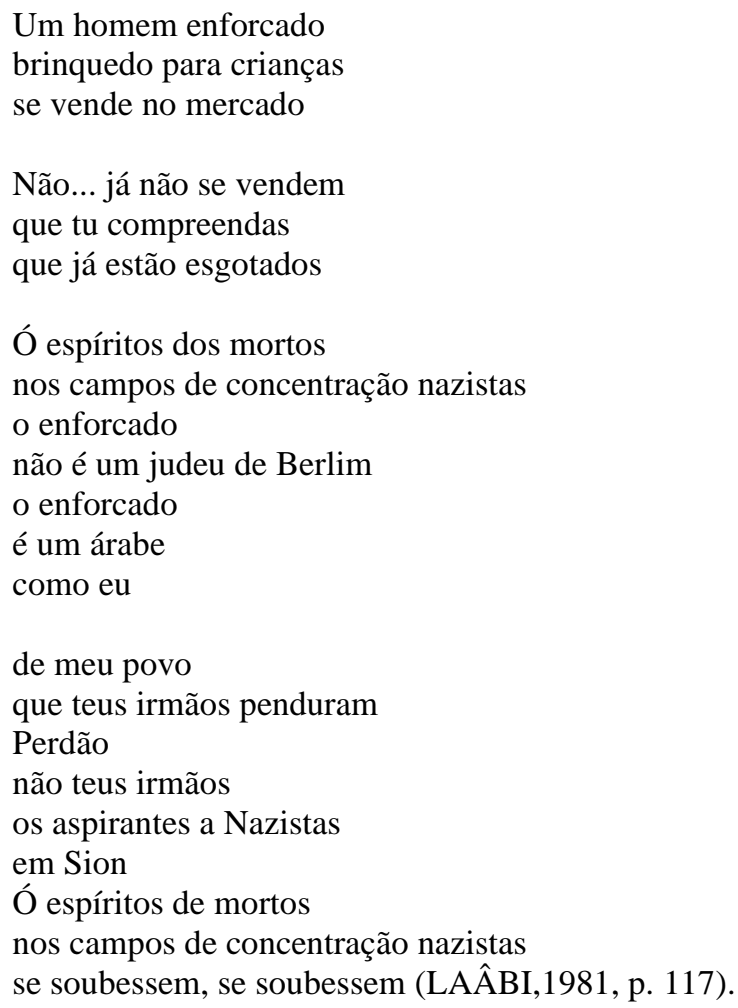

Nesse poema, o eu-lírico expressa com objetividade as duas faces do antissemitismo: primeiro, o praticado em solo europeu pelos nazistas contra os judeus; e, depois, o levado a cabo, como um retorno do reprimido, pelo Estado sionista contra os palestinos.

Se a primeira solução final para a aporia judeu e não judeu foi propugnada pelo fundador do sionismo moderno, Theodor Herzl, por meio da expulsão dos judeus do continente europeu; se a segunda, por sua vez, foi implementada pelo nazismo a partir da política de extermínio do $3^{\circ}$ Reich; a terceira paradoxalmente foi assumida pelo próprio Estado sionista.

Este, o Estado sionista, em nome, talvez, de ser mais europeu do que europeu; em nome do Antigo Testamento da metafísica do Ocidente ou do Ocidente como uma construção metafísica, uma presença a si, passou a adotar como solução final a 
excomunhão do lado não europeu de si mesmo, a partir do extermínio sem trégua do palestino, essa alteridade absoluta, logo matável.

O poema "O enforcado", do poeta palestino, Salim Jabran, invoca, incisivamente, a memória histórica do oprimido, exigindo coerência, de tal modo que, ao terminar a leitura do último verso, seja possível perguntar: quem é o enforcado, o palestino ou o judeu?

A ambiguidade aporética é retomada no poema em tela, dessa vez por meio de uma terceira pessoa ao mesmo tempo do singular e do plural (ele, o espírito; e eles, os mortos), "ó espírito dos mortos".

Sim, somos europeus e não somos europeus, porque somos igualmente povos do planeta Terra.

\section{UM BREVÍSSIMO E INCONCLUSO FIM}

Retomando o penúltimo capítulo "Elementos do Antissemitismo: Limites do esclarecimento" da obra Dialética do esclarecimento, de Adorno e Horkheimer (1985), observamos que o esclarecimento regressivo, sob o controle do $3^{\circ}$ Reich, serviu para produção de um Estado totalitário que, sob o endosso da maioria da população alemã, cometeu uma política antissemita, preconceituosa e truculenta ao povo judeu.

Observamos também que essa mesma prática antissemita autoritária se reproduziu no Oriente contra os povos árabes da Palestina. O historiador britânico, Arnold J. Toynbee, em sua obra A história e a moral no Oriente Médio, comentou a respeito:

\footnotetext{
A tragédia da história judaica recente é que, em vez de aprenderem com o sofrimento, os judeus iriam fazer a outrem, os árabes, o mesmo que lhes tinham feito outros, os nazistas (...) Deixar de aprender com o sofrimento, e infligir aos outros alguns dos malefícios que nos foram infligidos, são pecados em que todos os seres humanos tem tendência a cair. Esta é uma das mais odiosas e mais desesperadas características de nossa natureza humana comum (TOYNBEE, 1970, p. 23-24).
}

Obviamente, que o esclarecimento, traduzido nos avanços tecnológicos e científicos do poderio bélico do Estado de Israel foi fundamental para a reprodução dessa lógica racista e autoritária implementada contra os palestinos. 
No entanto, o esclarecimento regressivo, nos termos de Adorno e Horkheimer, não pode ser concebido como uma fatalidade do avanço técnico-científico, como se fosse o moto-continuo imanente ao progresso tecnológico.

O esclarecimento regressivo tem história. É herdeiro do longo pesadelo da tradição do oprimido, que detém o seguinte percurso, no Ocidente: civilizações escravocratas, como a romana e a grega; Idade Média feudal, com seus senhores de terra e camponeses superexplorados, seus reis e súditos; modo de produção capitalista, com o capital acumulando poder e riqueza às custas da classe operária mundial.

O esclarecimento regressivo, não sendo uma fatalidade histórica, objetiva-se por meio da relação saber/poder, sob o signo da dominação de classe. A apropriação das forças produtivas pelas classes dominantes engendra sempre o esclarecimento regressivo.

O orientalismo, compreendido como ideologia das oligarquias coloniais, capitalistas e imperialistas, como um pesadelo da história, pode ser, enfim, definido como o resultado de um processo histórico de longa duração; como a contraparte esclarecida e submetida, para ser sacrificada no altar do mito cosmogônico da formação mística e messiânica do Ocidente.

Os poemas, aqui analisados, no entanto, demandam outro esclarecimento; um esclarecimento lírico, típico da estética realista, que afirma o porvir, pela resistência e luta de classes da particularidade subjetiva palestina, humanizando-se no ato mesmo de recusar, pela práxis lírica, a condição de ser objeto do orientalismo, porque se propõe a ser o sujeito de seu próprio esclarecimento emancipador.

\section{Referências}

ADORNO, Theodor W.; HORKHEIMER, Max. Elementos do Antissemitismo: Limites do esclarecimento". In: ADORNO, Theodor W. e HORKHEIMER, Max. Dialética do esclarecimento: fragmentos filosóficos. Rio de janeiro: Zahar, 1985, p. 99-139.

LAÂBI, Abdellatif (Org.). A Poesia Palestina de Combate. Rio de Janeiro: Achiamé, 1981.

LOSURDO, Domenico. A linguagem do império: léxico da ideologia estadunidense. São Paulo: Boitempo, 2010.

LUKCÁCS, György. Estética I: cuestiones previas y de principio. Barcelona: Grijalbo, 1966. 
. Marx e Engels como historiadores de literatura. São Paulo: Boitempo, 2016.

SAID. Edward W. A questão da Palestina. São Paulo: Unesp, 2012.

Orientalismo: o oriente como invenção do ocidente. São Paulo: Companhia das Letras, 1990.

SODRÉ, Nélson Werneck. A ideologia do colonialismo: seus reflexos no pensamento brasileiro. Rio de Janeiro: Instituto Superior de Estudos Brasileiros, 1961.

TOYNBEE, Arnold J. A história e a moral no Oriente Médio. Petrópolis, RJ: Paralelo, 1970.

Recebido em: 24/05/2021

Aceito em: 01/08/2021 